\title{
Pelibatan Masyarakat dalam Persiapan Penetapan Situs Gunung Wingko, Bantul sebagai Cagar Budaya
}

\author{
Anggraeni \\ Departemen Arkeologi, Fakultas Ilmu Budaya, Universitas Gadjah Mada \\ Korespondensi: anggra_eni@ugm.ac.id \\ Tim Pengabdian kepada Masyarakat: \\ Anggraeni, Tito M. Rizky, Sheila Ayu Rachmadiena, M. Dziyaul F. Arozain, M. Faiz
}

\begin{abstract}
The use of Gunung Wingko for modern settlements has a significant impact on the preservation of the site. One of the efforts that can be done to prevent the widespread damage to the site is by disseminating important values and determining the site as a cultural heritage. Considering that this stipulation can trigger conflict, it is necessary to carry out careful preparation accompanied by socialization of the values (culture and knowledge) and dialogue with stakeholders through FGD. Sanden Fair, which is an annual event, is one of the means of disseminating research results that have long been carried out at the Mount Wingko Site and the importance of the site. In order to maintain awareness of the importance of the site, an embryo of Gunung Wingko Site Information Center was created. In the future, local communities can be involved in filling out the materials and managing the Information Center that has been initiated. In a FGD involving all stakeholders in Bantul Regency and the DIY Cultural Heritage Conservation Office, it was found that the designation of Gunung Wingko as a cultural heritage was constrained by the absence of site delineation. The Department of Archaeology FIB UGM team proposes gradual protection, starting from the determination of the area of the core zone which refers to the results of previous research. Communities living around the site also need to be involved in the activity of determining Gunung Wingko as a cultural heritage and need to get accurate information about the consequences and impacts of determining the site.
\end{abstract}

Key words: cultural heritage; dissemination; Informasi Center; local communities involvement

\begin{abstract}
Abstrak
Pemanfatan Situs Gunung Wingko untuk permukiman baru telah membawa dampak yang signifikan terhadap kelestarian situs. Salah satu upaya yang dapat dilakukan untuk mencegah meluasnya kerusakan situs adalah dengan melakukan sosialisasi nilai penting dan penetapan situs sebagai Cagar Budaya. Mengingat penetapan tersebut dapat memicu konflik, maka perlu dilakukan persiapan matang disertai sosialisasi nilai penting (kebudayaan dan pengetahuan) dan dialog dengan para stakeholder melalui FGD. Sanden Fair yang merupakan acara tahunan menjadi salah satu sarana sosialisasi hasil penelitian yang telah lama dilakukan di Situs Gunung Wingko dan nilai penting situs. Guna menjaga kesadaran tentang nilai penting situs tersebut, maka dibuatlah embrio Pusat Informasi Situs Gunung Wingko. Masyarakat setempat ke depan dapat dilibatkan dalam pengisian materi dan pengelolaan Pusat Informasi yang telah dirintis. Dalam FGD yang melibatkan seluruh stakeholder di Kabupaten Bantul dan Balai Pelestarian Cagar Budaya DIY diketahui bahwa penetapan Gunung Wingko sebagai Cagar Budaya terkendala oleh belum adanya delineasi situs. Tim Departemen Arkeologi FIB UGM
\end{abstract}


mengusulkan pelindungan bertahap, dimulai dari penetapan luasan zona inti yang mengacu pada hasil penelitian terdahulu. Masyarakat yang tinggal di sekitar situs juga perlu dilibatkan dalam kegiatan penetapan Gunung Wingko sebagai Cagar Budaya dan perlu mendapat informasi yang tepat mengenai konsekuensi dan dampak penetapan situs.

Kata kunci: cagar budaya; sosialisasi; Pusat Informasi; pelibatan masyarakat setempat

\section{Pendahuluan}

\section{Latar belakang}

Gunung Wingko merupakan sebutan yang dulu digunakan penduduk Sanden, Bantul untuk menyebut bagian dari dua deret bukit pasir atau beting gisik (beach ridge) di utara pantai Samas yang mengandung banyak wingko atau kereweng (fragmen gerabah dalam Bahasa Jawa). Kedua deret bukit pasir yang memanjang sejajar pantai tersebut secara administratif masuk dalam wilayah tiga kelurahan, yaitu Gadingharjo, Srigading dan Tirtohargo di Kecamatan Sanden (Nitihaminoto, 1999). Pembentukan beting gisik sendiri merupakan fenomena alam yang menarik (Sunarto, 1986), lebih-lebih dengan adanya kandungan sisa permukiman lama didalamnya.

Keberadaan fragmen gerabah di Gunung Wingko cukup mudah diketahui dan hingga sekarang masih banyak ditemukan berserakan di sekitar pemukiman penduduk di Dusun Tegalrejo dan makam di Dusun Ngepet yang terletak di kiri kanan jalan raya Samas. Selain fragmen gerabah, penduduk yang bermukim pada area bukit pasir tersebut, juga mendapatkan tulang dan gigi fauna, rangka manusia, keramik serta logam ketika mereka melakukan aktivitas sehari-hari, seperti menggali lubang dan menambang pasir (Anggraeni, 2018).

Survey dan ekskavasi pada 1972 hingga 1998 oleh para arkeolog, khususnya tim Balai Arkeologi DIY berhasil mengungkap temuan-temuan arkeologis yang didominasi oleh fragmen gerabah di Gunung Wingko. Temuan-temuan tersebut menghasilkan informasi penting tentang keberadaan permukiman dari masa awal abad Masehi hingga abad XVII, seperti tertuang dalam disertasi Dr. Gunadi Nitihaminoto (Rangkuti et al. 2018). Sayangnya hasil-hasil penelitian arkeologi terkait Situs Gunung Wingko yang ditulis dalam bentuk laporan penelitian, disertasi, atau naskah tugas akhir mahasiswa tidak bisa diakses oleh masyarakat luas secara bebas, sedangkan publikasi pada jurnal nasional dan internasional juga terbatas.

Setelah kegiatan penelitian yang melibatkan penduduk setempat sebagai tenaga pembantu tersebut berlalu, tidak ada kegiatan lanjutan yang signifikan, khususnya kegiatan pengelolaan situs yang meliputi kegiatan pelestarian dan pemanfaatan. Situs Gunung Wingko pun berangsur-angsur dilupakan. Bangunan permukiman yang menempati situs sedikit demi sedikit bertambah. Sementara itu kegiatan penambangan pasir pun terus menerus dilakukan. Tidak adanya upaya pelindungan secara hukum menyebabkan situs tersebut semakin rusak. Saat ini situs dan nama "Gunung Wingko" hampir tidak dikenal lagi oleh masyarakat Sanden sendiri. Keberadaan bukit pasir tersebut hampir tidak terlihat karena tertutup oleh permukiman modern dan sebagian sudah rusak akibat ditambang untuk memperoleh lahan datar untuk memperluas lahan budidaya tanaman dan aktivitas lainnya (Anggraeni, 2018). 
Berdasarkan pengakuan sejumlah warga yang bermukim di Gunung Wingko, diketahui bahwa keberadaan ribuan fragmen gerabah dengan tera (cap) anyaman atau tenun di sekitar tempat tinggal mereka sebenarnya selama ini disadari dan menarik perhatian mereka. Akan tetapi, mereka tidak tahu bahwa benda-benda tersebut memiliki nilai penting. Mereka juga tidak tahu bahwa pada bukit pasir di sekitar kediaman mereka terdapat empat lapisan budaya yang mengandung bukti aktivitas manusia sejak awal abad Masehi hingga sekitar abad XVII (Nitihaminoto, 1999; 2001; Alifah, 2012b). Sisa permukiman di situs ini menunjukkan bahwa Gunung Wingko memiliki nilai penting bagi ilmu pengetahuan dan sejarah budaya setempat. Bukti kehidupan prasejarah di wilayah Kabupaten Bantul hingga kini baru didapatkan di situs ini.

Kegiatan Pengabdian kepada Masyarakat $(\mathrm{PkM})$ yang difokuskan di Situs Gunung Wingko oleh dosen dan mahasiswa Departemen Arkeologi FIB UGM, yang mulai dilaksanakan pada tahun 2018 (Anggraeni, 2018) dilandasi oleh permasalahan dan keprihatinan terhadap kondisi situs yang makin rusak. Luas dan ketinggian beting gisik Gunung Wingko yang juga merupakan fenomena alam yang penting ini dari waktu ke waktu semakin berkurang akibat kegiatan penambangan pasir. Kegiatan menambang dipandang menguntungkan oleh masyarakat terutama untuk memperluas lahan kebun dan permukiman. Bahkan selanjutnya, pasir yang ditambang juga memiliki nilai ekonomi karena laku dijual, sehingga aktivitas itu semakin meningkat.

Hasil kegiatan PkM 2018 menunjukkan bahwa sosialisasi tentang keberadaan dan nilai penting Situs Gunung Wingko serta upaya pengelolaan (pelestarian dan pemanfaatan) situs perlu melibatkan semua stakeholder yang meliputi masyarakat setempat, Pemerintah Kabupaten Bantul, Dinas Kebudayaan Bantul, Balai Pelestarian Cagar Budaya DIY, Balai Arkeologi DIY, Dinas Kebudayaan Provinsi DIY, Tim Ahli Cagar Budaya Kabupaten dan Provinsi, serta Universitas Gadjah Mada (Anggraeni, 2018). Namun upaya pelindungannya saat ini masih terkendala oleh tidak adanya payung hukum terhadap situs, sehingga pemanfaatan situs bertentangan dengan upaya pelestariannya. Oleh karena itu, upaya pelindungan melalui penetapan Gunung Wingko sebagai Cagar Budaya perlu segera diwujudkan.

\section{Tujuan kegiatan}

1. Menyebarluaskan nilai penting Situs Gunung Wingko kepada masyarakat;

2. Mewujudkan upaya pelindungan situs Gunung Wingko melalui penetapan sebagai Cagar Budaya;

3. Mewujudkan upaya pemanfaatan situs agar berguna bagi masyarakat setempat dan masyarakat luas.

\section{Sasaran kegiatan}

1. Terbukanya wawasan masyarakat tentang nilai penting Situs Gunung Wingko;

2. Terwujudnya pelindungan terhadap kelestarian Situs Gunung Wingko;

3. Terwujudnya pemanfaatan Situs Gunung Wingko berbasis pelestarian.

\section{Pendekatan Pelaksanaan Program}

Kegiatan PkM yang saya lakukan bersama mahasiswa Departemen Arkeologi UGM pada 
tahun 2019 merupakan kelanjutan dari kegiatan PkM Tahap I (2018). Upaya sosialisasi nilai penting, pelindungan dan pemanfaatan situs merupakan bentuk pendampingan kepada masyarakat yang berlangsung terus menerus. Hal ini mengingat kepentingan ekonomi dan upaya pelestarian situs belum berjalan seiring. Metode yang saya lakukan untuk mencapai tujuan kegiatan PkM Tahap II meliputi:

1. observasi kondisi terkini gumuk pasir di wilayah Desa Srigading dan Gadingharjo untuk mengetahui bentuk ancaman terhadap kelestarian situs, disertai wawancara dengan penduduk setempat;

2. sosialisasi nilai penting situs melalui diskusi interaktif dan pameran pada Sanden Fair 2019 di Balai Desa Gadingharjo;

3. Focus Group Discussion (FGD) yang melibatkan pemuda, tokoh masyarakat dan instansi yang terkait dengan pelestarian situs dan tata ruang pesisir selatan Kabupaten Bantul;

4. penyiapan embrio Pusat Informasi Situs Gunung Wingko

\section{Pelaksanaan Program \\ Observasi dan Wawancara}

Observasi terhadap kondisi Situs Gunung Wingko untuk mengetahui aktivitas dan perubahan yang terjadi pada situs merupakan upaya yang perlu dilakukan secara berkelanjutan. Berdasarkan hasil observasi pada tahun 2018 diketahui bahwa area gumuk pasir yang tersisa dan layak untuk dilindungi terdapat di Dusun Tegalrejo. Dusun ini mencakup area gumuk pasir yang terletak di sebelah timur jalan raya Samas. Meskipun sejumlah rumah sudah didirikan di sekitar dan di atas gumuk pasir, tidak jauh dari jalan raya dan jalan dusun, pada gumuk pasir tersebut masih terdapat area yang bebas dari bangunan dan pada permukaannya banyak ditemukan fragmen gerabah (Anggraeni, 2018). Akan tetapi, dalam pemantauan terhadap kondisi situs yang saya lakukan bersama mahasiswa Arkeologi UGM pada pertengahan tahun 2019, pada sisi barat area tersebut telah didirikan dua bangunan rumah baru. Kepemilikan lahan pada tempat rumah tersebut didirikan juga sudah beralih kepada pendatang baru. Kondisi ini tentu sangat memprihatinkan dan mendorong Tim PkM Departemen Arkeologi FIB UGM untuk segera merealisasikan rencana pelindungan terhadap situs.

Observasi pada tahun 2019 difokuskan ke arah timur, mencakup bagian timur Dusun Tegalrejo hingga Dusun Soge Sanden (wilayah Desa Srigading) dan ke Dusun Karanganyar (Desa Gadingharjo). Hasilnya memperkuat optimisme bahwa masih ada area yang tersisa, yang masih dapat memberikan gambaran tentang keberadaan dan bentuk gumuk pasir Gunung Wingko kepada masyarakat. Beberapa titik yang layak dilindungi terletak di wilayah Dusun Tegalrejo dan Soge Sanden. Berdasarkan wawancara dengan Bapak Muji Sarjono (Pak Besar) diketahui bahwa pada gumuk pasir di lahan miliknya, pada tahun 2000 pernah ditemukan sejumlah artefak dari perunggu dan besi ketika dilakukan penambangan pasir setinggi 3 meter dari permukaan sekarang. Temuan artefak logam telah dilaporkan kepada Balai Pelestarian Cagar Budaya DIY (dulu Suaka Peninggalan Sejarah dan Purbakala DIY), dan sebagian disimpan di Museum Sonobudoyo sampai sekarang.

Berdasarkan observasi di wilayah Gadingharjo dan wawancara dengan Kepala 


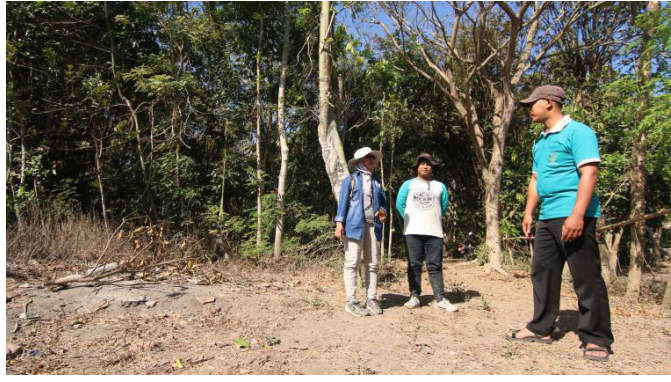

Gambar 1. Observasi kondisi terkini Situs Gunung Wingko pada Agustus 2019 (Dokumentasi oleh Sheila Ayu Rachmadiena)

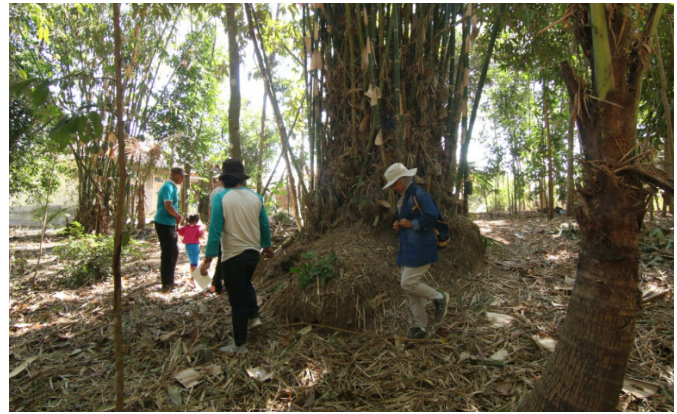

Gambar 2. Peninjauan lokasi temuan fragmen gerabah di Dusun Karanganyar, Desa Gadingharjo bersama Bapak Kepala Desa Gadingharjo (Dokumentasi oleh Sheila Ayu Rachmadiena)

Desa Gadingharjo, Bapak Aan Indra Nursanta, S.S., diketahui bahwa gumuk pasir di wilayah Gadingharjo telah habis diratakan untuk lahan bercocok tanam. Kepala Desa Gadingharjo juga menyampaikan bahwa di lahan orangtuanya juga pernah ditemukan guci dan batu pipisan. Batu pipisan merupakan alat batu yang umum dikenal sebagai salah satu alat untuk membuat jamu. Selain itu, fragmen gerabah juga banyak ditemukan, terutama di tepi Sungai Winongo Kecil yang berada di sebelah barat atau berseberangan dengan Dusun Ngepet, Desa Srigading (lihat Gambar 1 dan 2).

\section{Diskusi Interaktif dan Pameran dalam Sanden Fair 2019}

Keikutsertaan Tim PkM Departemen Arkeologi dalam pameran Sanden Fair 2018 bersama dengan Balai Arkeologi DIY di Balai Desa Gadingsari, secara langsung telah membuka wawasan dan memberi kesempatan kepada masyarakat Sanden untuk berdiskusi tentang keberadaan Situs Gunung Wingko. Pameran yang kami laksanakan tahun ini merupakan tanggapan atas permintaan pemerintah Kecamatan Sanden untuk mengisi stan dalam Sanden Fair 2019. Oleh karena itu, undangan pemerintah Kecamatan Sanden untuk kembali mengadakan pameran dalam Sanden Fair 2019 di Kelurahan Gadingharjo kami sambut dengan baik. Bersama dengan Balai Arkeologi D. I. Yogyakarta, kami menampilkan foto-foto hasil penelitian arkeologi di Situs Gunung Wingko oleh Balai Arkeologi DI Yogyakarta, dilengkapi dengan temuan artefaktual dan ekofaktual hasil observasi yang dilakukan oleh Tim PkM Departemen Arkeologi UGM pada 2018 dan 2019. Stan yang kami buka tahun ini tetap menarik perhatian masyarakat, mengingat masyarakat setempat belum banyak yang mengetahui keberadaan situs arkeologi di sekitar permukiman mereka.

Pengetahuan masyarakat tentang keberadaan Situs Gunung Wingko yang masih terbatas terungkap melalui diskusi tentang nilai penting Situs Gunung Wingko pada acara pembukaan Sanden Fair pada 23 Agustus 2019. Diskusi yang dihadiri oleh para pejabat di lingkungan Pemda Kabupaten Bantul, anggota DPRD, staf Kecamatan Sanden dan pemuka masyarakat setempat menjadi ajang tukar pikiran dan pembuka wawasan tentang nilai penting situs dan kebijakan terkait pelestarian situs (Gambar 3). Pertanyaan dan diskusi tentang situs Gunung Wingko berlanjut dalam peninjuan materi pameran. 


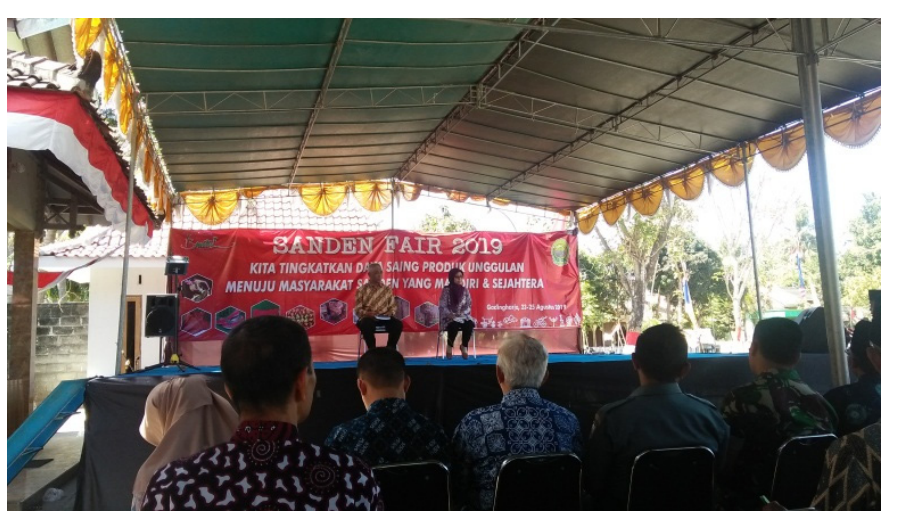

Gambar 3. Diskusi interaktif dalam Sanden Fair 2019 (Dokumentasi oleh Wiji Tri Ningsih)
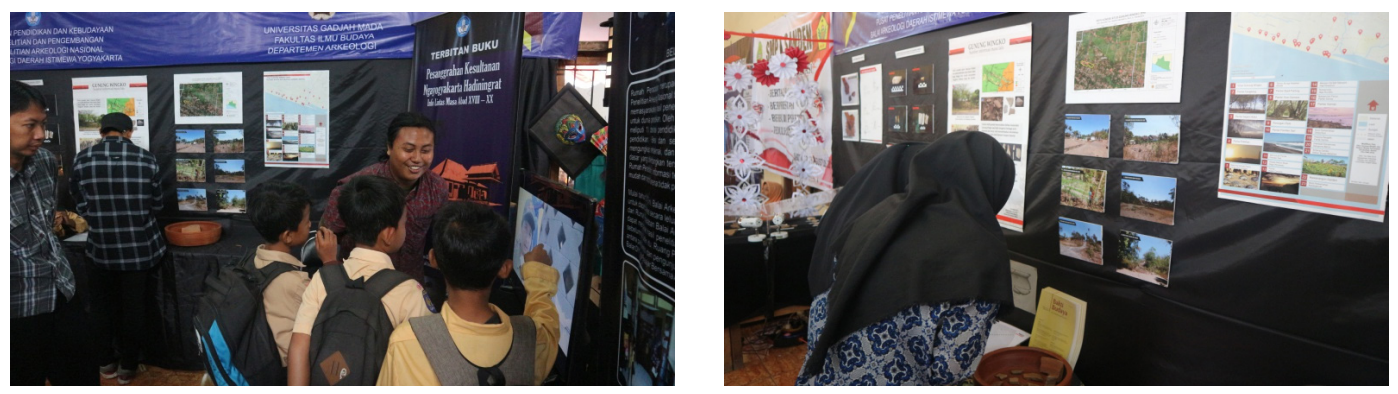

Gambar 4. Pameran potensi Situs Gunung Wingko dalam Sanden Fair 2019 (Dokumentasi oleh M. Faiz)

Dibandingkan pameran sebelumnya, sepanjang kegiatan pameran berlangsung, tidak terlalu banyak pengunjung yang datang. Meskipun demikian, pengunjung yang hadir memiliki antusiasme tinggi dan banyak mengajukan pertanyaan (Gambar 4). Selama pameran berlangsung, dapat dijaring berbagai informasi terkait dengan temuantemuan data artefaktual oleh masyarakat yang bermukim di situs, potensi-potensi lokal yang dapat menunjang pemanfaatan situs, dan generasi muda yang punya kepedulian terhadap keberadaan situs. Keberadaan objek wisata yang ada di sepanjang pesisir selatan wilayah Kecamatan Sanden menjadi peluang untuk sekaligus memperkenalkan Situs Gunung Wingko kepada wisatawan. Potensi yang dimiliki oleh masyarakat Sanden, seperti kemampuan menganyam dan membuat makanan olahan untuk oleh-oleh, menjadi peluang yang dapat dikembangkan dan dikaitkan dengan pemanfaatan Situs Gunung Wingko sebagai objek wisata.

Di sela-sela penyelenggaraan pameran juga dilakukan diskusi dengan R.M. Cahyo Bandono, M.T, pemilik Puri Brata meditation resort yang juga berfungsi sebagai home stay (Gambar 5). Keberadaan home stay yang sudah sering dikunjungi wisatawan asing serta objek-objek wisata di sekitar pesisir selatan Kabupaten Bantul menjadi salah satu peluang untuk melindungi kelestarian Situs Gunung Wingko. Melalui upaya pemanfaatan situs sebagai objek wisata, diharapkan masyarakat lokal tergugah untuk ikut memelihara kelestarian situs. R.M. Cahyo Bandono, M.T sendiri secara visioner telah mendorong berkembangnya potensi lokal, seperti pembuatan jamu oleh penduduk di Desa Gadingharjo dan kegiatan cocok tanam secara tradisional yang dapat menjadi objek wisata. Cocok tanam tradisional yang melibatkan wisatawan asing sejak proses 


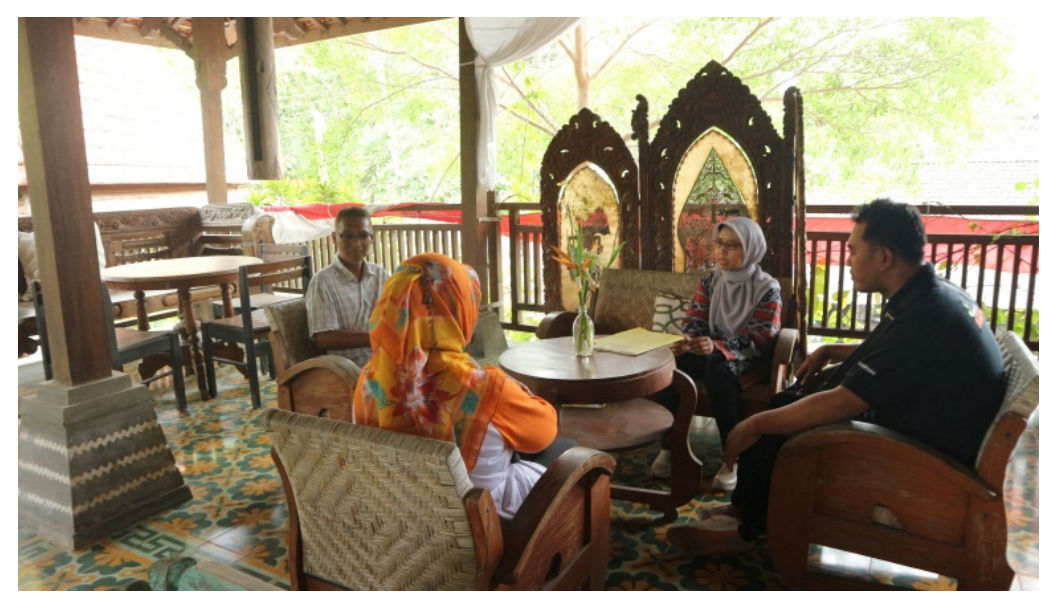

Gambar 5. Diskusi tentang posisi Situs Gunung Wingko dalam pengembangan wisata pesisir selatan Kecamatan Sanden dengan R.M. Cahyo Bandono, M.T. (pemilik Puri Brata Meditation Resort), Bapak Aan Indra Nursanta, S.S. (Kepala Desa Gadingharjo), dan Ibu Dewi Iriani, S.P.

(Kepala Seksi Ekonomi, Pembangunan, dan Lingkungan Hidup Kecamatan Sanden) (Dokumentasi oleh Sheila Ayu Rachmadiena)

tanam hingga panen menjadi pengikat wisatawan tersebut untuk datang kembali ke lokasi. Kegiatan semacam itu dapat menjadi pendorong tumbuhnya wisata minat khusus dengan Situs Gunung Wingko sebagai objek utamanya. Dalam hal ini eksplorasi potensi wisata minat khusus, seperti ziarah terhadap petilasan-petilasan yang ada di sekitar Situs Gunung Wingko dan sudah dikenal oleh masyarakat luas, perlu dilakukan dan diintegrasikan dengan Situs Gunung Wingko.

\section{Focus Group Discussion (FGD)}

Focus Group Discussion (FGD) yang melibatkan semua stakeholders di Kabupaten Bantul merupakan upaya untuk menjaring pendapat dalam persiapan penetapan Situs Gunung Wingko sebagai Cagar Budaya dan penyiapan Pusat Informasi Gunung Wingko. Penetapan Situs Gunung Wingko sebagai Cagar Budaya merupakan upaya penting agar situs terlindungi dari kegiatan pemanfaatan yang dapat mengancam kelestarian situs. Adapun pendirian Pusat Informasi Situs Gunung Wingko merupakan upaya untuk menyediakan berbagai informasi tentang bentukan alam yang langka yang di dalamnya terkandung tinggalan arkeologis. Berbeda dari tinggalan arkeologis yang bersifat monumental, Situs Gunung Wingko memerlukan cara khusus agar keberadaan dan nilai pentingnya dapat dipahami oleh masyarakat luas.

Berkaitan dengan upaya di atas, maka Tim PkM Departemen Arkeologi UGM mengundang sejumlah narasumber untuk hadir pada FGD 30 September 2019 di kantor Kecamatan Sanden. Dalam FGD tersebut hadir Bapak Camat Sanden, Ketua Tim Ahli Cagar Budaya (TACB) Kabupaten Bantul, staf Balai Pelestarian Cagar Budaya DIY, staf Dinas Kebudayaan Kabupaten Bantul, anggota DPRD Kabupaten Bantul, staf BPD Srigading, Koramil Sanden, staf Bapedda Bantul, staf Dinas Pariwisata Kabupaten Bantul, staf Dinas Pertahanan dan Tata Ruang Kabupaten Bantul, mahasiswa Arkeologi FIB UGM, tokoh masyarakat dan warga setempat. FGD tersebut dilaksanakan untuk mencari pemecahan masalah yang dapat disepakati bersama, khususnya terkait dengan 

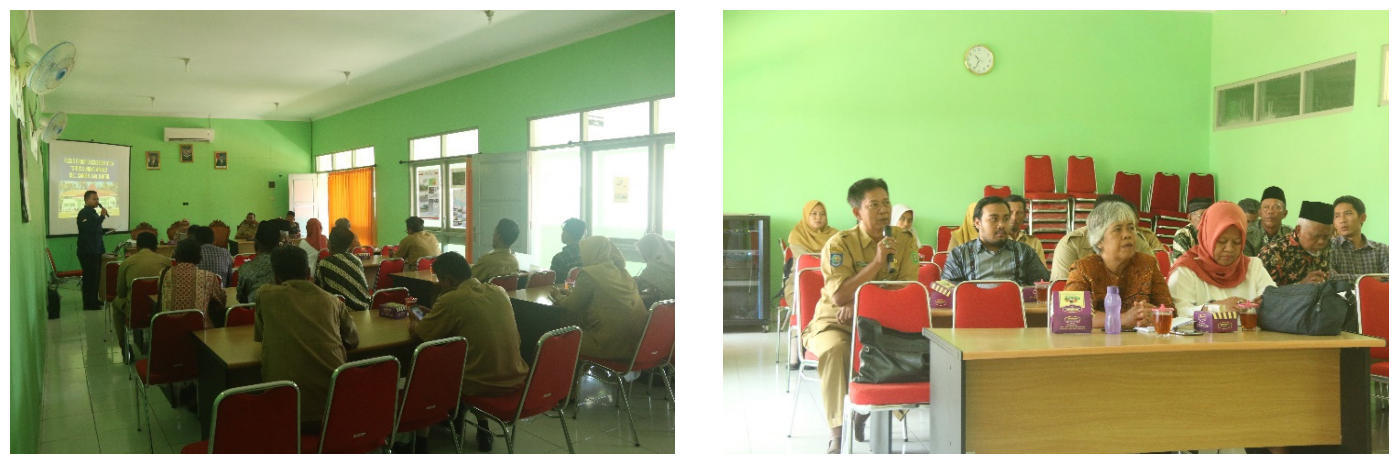

Gambar 6. FGD Gunung Wingko tahun 2019 di Kantor Kecamatan Sanden (Dokumentasi oleh Sheila Ayu Rachmadiena)

pemanfaatan situs dan menentukan pilihan aksi yang akan dilakukan (Gambar 6).

Menurut Ketua TACB Kabupaten Bantul, Dra. Andi Riana, pengajuan Situs Gunung Wingko sebagai Situs Cagar Budaya kepada Bupati Bantul sudah dilaksanakan dan rekomendasi sebagai situs cagar budaya sudah disiapkan. Masalahnya, luas situs yang perlu dilindungi dan batas-batasnya belum ditentukan. Penentuan luas dan batas tersebut diperlukan dalam pengajuan usulan penetapan situs sebagai Cagar Budaya. Di samping itu, kepemilikan lahan yang terletak di gumuk pasir perlu dicatat, mengingat lahan sudah dikapling dan bersertifikat. Penentuan luas situs dan area yang perlu dilindungi perlu dibahas bersama dengan semua stakeholder disertai penjelasan kepada warga yang bermukim di area tersebut agar tidak menimbulkan keresahan.

Menurut staf BPCB DIY (Wiwit Kasiyati, S.S., M.A.) proses pelindungan dimulai dari zona inti. Anggaran zonasi dan delineasi ada pada Dinas Kebudayaan Bantul dan dinas-dinas terkait, seperti Dinas Kebudayaan DIY, sedangkan pelaksananya adalah staf BPCB DIY. Dalam hal ini, Balai Arkeologi DIY dan Departemen Arkeologi UGM dapat membantu merekomendasikan zona yang paling penting untuk dilindungi (zona inti), zona penyangga dan zona pendukung. Anggota DPRD Kabupaten Bantul, Bapak Sadji Tirto H., mengingatkan bahwa sosialisasi rencana dan dampak kegiatan yang berkaitan dengan langkah-langkah penetapan Cagar Budaya, perlu dilakukan. Di samping itu, menurut Bapak Aan Indra Nursanta, Kepala Desa Gadingharjo, dampak ekonomi pasca penetapan Gunung Wingko sebagai Cagar Budaya, baik positif maupun negatif, juga perlu dijelaskan kepada masyarakat setempat.

Mengingat penentuan delineasi dan luas situs memerlukan waktu panjang dan biaya yang tidak sedikit, sedangkan pelindungan terhadap situs mendesak untuk dilakukan, maka Tim PkM Departemen Arkeologi mengusulkan untuk memanfaatkan data hasil penelitian Balai Arkeologi DIY dalam penentuan zonasi situs. Penelitian Situs Gunung Wingko yang intensif dilakukan oleh Balai Arkeologi DIY, menghasilkan informasi berupa distribusi temuan arkeologis secara vertikal dan horizontal, serta peta situs yang dapat digunakan untuk menentukan delineasi dan pembagian zona. Akan tetapi, mengingat sebagian besar area situs telah dimanfaatkan untuk permukiman, maka Tim PkM Departemen Arkeologi mengusulkan batas zona inti berdasarkan kepadatan temuan dan kondisi situs saat ini, untuk segera dilindungi. Usulan batas zona inti dan delineasi di atas kertas tersebut (lihat Gambar 7) akan dicek oleh Balai Pelestarian Cagar 

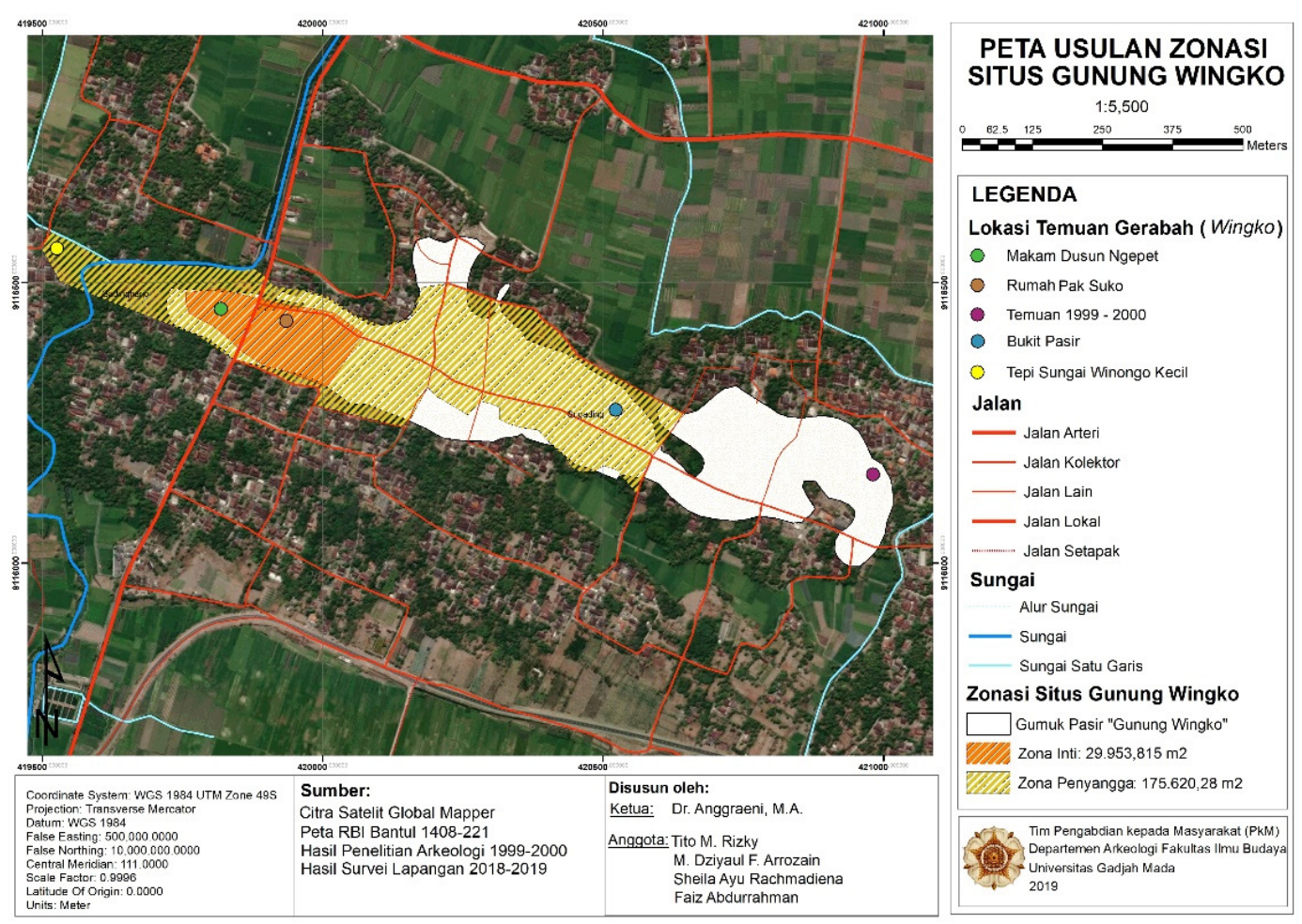

Gambar 7. Usulan delineasi dan zonasi Situs Gunung Wingko (Disiapkan oleh Tito M. Rizky)

Budaya DIY dan instansi terkait pada tahun-tahun berikutnya.

Pada tahap berikutnya, melalui FGD yang berkelanjutan, masyarakat yang tinggal di sekitar situs didorong dan didampingi untuk:

- terlibat aktif dalam penyusunan rencana pelestarian situs dalam jangka pendek, jangka menengah, dan jangka panjang bersama-sama dengan akademisi, lembaga penelitian dan pelestari warisan budaya yang ada di DIY. Kegiatan yang dapat dilakukan antara lain merencanakan upaya pengendalian pembangunan di area situs yang sudah terlanjur menjadi permukiman;

- melakukan upaya sosialisasi nilai penting situs secara berkelanjutan secara mandiri. Bantul Expo dan Sanden Fair yang diadakan tiap tahun dapat dijadikan sarana untuk sosialisasi keberadaan Situs Gunung Wingko kepada masyarakat. Sebaliknya, Sanden Fair dapat menjadi ajang untuk menggali potensi lain yang dimiliki masyarakat lokal dan dapat menunjang keberadaan Pusat Informasi Gunung Wingko, seperti kerajinan dan kuliner, termasuk jamu.

- menggali potensi budaya yang dimiliki oleh masyarakat lokal. Menurut Bapak Joko dari Dinas Kebudayaan Bantul, pembuatan garam secara tradisional di wilayah Sanden sudah didata dan dimasukkan daftar warisan budaya tak benda.

- menggali potensi ekonomi yang dimiliki oleh masyarakat lokal agar kegiatan pelestarian Situs Gunung Wingko dan upaya peningkatan kesejahteraan masyarakat yang tinggal di sekitar dapat berjalan seiring.

- melibatkan masyarakat setempat untuk menggali sejarah lisan dan tradisi yang selama ini mereka ketahui, untuk menambah wawasan tentang Situs Gunung 
Wingko.

\section{Penyiapan Embrio Pusat Informasi Situs Gunung Wingko}

Upaya untuk mewujudkan "Pusat Informasi Situs Gunung Wingko" tidak mengalami kendala karena pada kegiatan FGD di Dusun Ngepet tahun 2018, Bapak Mono (salah satu warga Dusun Ngepet) sudah menawarkan rumahnya untuk menampilkan informasi tentang Situs Gunung Wingko dan hasil-hasil penelitian di situs tersebut. Rumah dengan arsitektur joglo tersebut sudah masuk di Google Map sebagai Griya Gunung Wingko. Dari hasil wawancara pada 2019 dengan Bapak Mono, diketahui bahwa kesadaran beliau tentang keberadaan Situs Gunung Wingko dan nilai pentingnya muncul pada saat FGD tahun 2018. Pada saat itu juga beliau yang hadir dalam FGD menawarkan rumahnya yang luas untuk menjadi embrio "Pusat Informasi Situs Gunung Wingko".

Kesadaran Bapak Mono merupakan bukti nyata dan optimisme untuk dapat melibatkan masyarakat lokal dalam mengelola dan melestarikan Situs Gunung Wingko. Bapak Cahyo Bandono, sebagai warga Desa Gadingharjo, mengusulkan untuk menyiapkan wisata virtual tentang Situs Gunung Wingko. Menanggapi usulan tersebut, informasi mengenai hasil penelitian arkeologi yang sudah dilakukan sangat penting untuk diungkap secara lebih detail dan divisualisasikan pada tahap $\mathrm{PkM}$ selanjutnya. Informasi yang dapat ditampilkan bukan hanya terkait dengan aktivitas sehari-hari yang dapat direkonstruksi dari data arkeologi yang ditemukan, tetapi juga terkait riwayat penemuan data arkeologis, baik secara sengaja (melalui ekskavasi) maupun secara tidak sengaja ketika warga setempat melakukan aktivitas. Display sederhana namun informatif yang ditampilkan di rumah Bapak Mono menjadi embrio atau awal pembentukan Pusat Informasi Situs Gunung Wingko (lihat Gambar 8 dan 9).

Mengingat sebagian besar artefak dan publikasi hasil ekskavasi oleh peneliti Balai Arkeologi DIY saat ini disimpan di Kantor Balai Arkeologi DIY, maka di Pusat Informasi Situs Gunung Wingko dibuatkan kode QR bagi masyarakat agar mereka dapat mengakses website instansi tersebut secara langsung, khususnya laman publikasi Balai Arkeologi DIY. Balai Arkeologi DIY juga sudah membuat Rumah Peradaban yang menyediakan informasi tentang hasil-hasil penelitian arkeologi yang diperuntukan bagi masyarakat luas. Publikasi lain terkait dengan hasil penelitian terhadap Situs Gunung Wingko juga dapat diakses oleh masyarakat luas melalui bank data yang telah disiapkan oleh Tim PkM, melalui layanan penyimpanan Google Drive. Bank data tersebut juga mencakup informasi mengenai keberadaan temuan dari Situs Gunung Wingko di beberapa instansi. Di ruang koleksi lantai 1 Balai Pelestarian Cagar Budaya DIY misalnya, tersimpan artefak dari hasil ekskavasi di Situs Gunung Wingko, berupa periuk dan fragmen wadah gerabah dengan nomor inventaris BG 14 dan BG 31, serta satu beliung yang sudah digosok dengan nomor inventaris BG 21. Periuk dan fragmen wadah gerabah disebutkan berasal dari wilayah Desa Srigading. Adapun artefak-artefak logam hasil temuan warga Dusun Soge Sanden, Bapak Muji Sarjono, disimpan dan menjadi koleksi Museum Sonobudoyo.

Dokumentasi kegiatan penelitian oleh mahasiswa di Laboratorium Arkeologi UGM juga dapat menjadi materi yang dapat diakses melalui bank data di layanan penyimpanan Google Drive. Demikian pula kajian terhadap hasil-hasil penelitian Situs Gunung Wingko yang kembali marak, baik untuk diangkat sebagai topik skripsi 

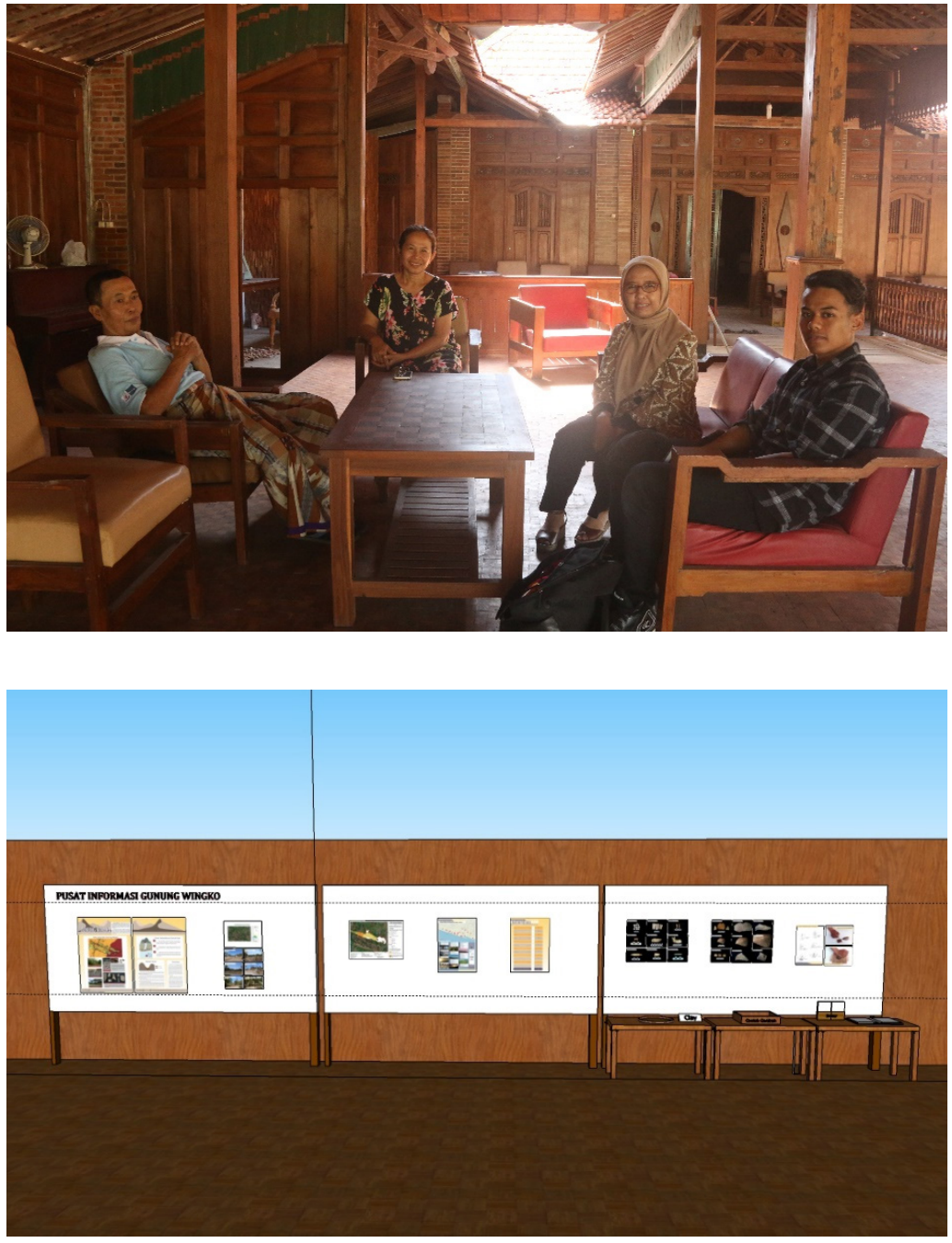

\section{Gambar 8.}

Kunjungan ke rumah Pak Mono untuk membahas lokasi embrio Pusat Informasi Situs Gunung Wingko (Dokumentasi oleh Sheila Ayu Rachmadiena)

Gambar 9. Rencana tata pamer materi di Pusat Informasi Situs Gunung Wingko (Disiapkan oleh Tito M. Rizki)

mahasiswa Arkeologi UGM maupun untuk dipublikasikan dalam jurnal (lihat Prayudi dan Suriyanto, 2019). Selain itu, penambahan materi yang dikumpulkan oleh masyarakat setempat, khususnya terkait sejarah lokal yang merupakan tradisi lisan dan budaya materi lainnya yang hampir punah dapat ditambahkan ke dalam bank data, sehingga dapat menjadi pendorong untuk memperkuat pelestarian situs dan pengkayaan Pusat Informasi Gunung Wingko.

\section{Refleksi Capaian Program}

Penetapan Situs Gunung Wingko sebagai Cagar Budaya merupakan langkah yang dirasa tepat untuk melestarikan situs tersebut dari berbagai ancaman. Mengingat kepemilikan lahan yang bersifat perorangan, Langkah menuju penetapan Cagar Budaya memerlukan waktu lebih panjang dan bijak, terutama berkaitan dengan pendekatan dan sosialisasi kepada pemilik.

Pemeliharaan dan keberlanjutan Pusat Informasi Situs Gunung Wingko perlu dijaga dengan membuat kesepakatan kerjasama pada $\mathrm{PkM}$ tahap berikutnya, dengan melibatkan Tim PkM Departemen Arkeologi, akademisi lain (seperti ahli geografi, sejarawan), tokoh 
masyarakat, dan generasi muda setempat. Saat ini sudah ada warga muda potensial yang bersedia untuk menjadi fasilitator Pusat Informasi Situs Gunung Wingko. Di awal, fasilitator Pusat Informasi Situs Gunung Wingko masih perlu didampingi oleh Tim $\mathrm{PkM}$, selanjutnya mereka yang diharapkan akan menjadi motor penggerak keberlanjutan Pusat Informasi Situs Gunung Wingko.

Masyarakat setempat juga didorong untuk menambah informasi mengenai Situs Gunung Wingko melalui pencatatan sejarah lokal yang dituturkan oleh tokoh masyarakat, pendokumentasian tradisi pembuatan garam dan tradisi lainnya yang langsung melibatkan pelaku. Dalam hal ini Tim PkM Departemen Arkeologi UGM dapat membantu memberikan masukan-masukan untuk menjaga keberlanjutan pusat informasi yang dapat menjadi objek wisata minat khusus tersebut.

Desa lain di wilayah Kecamatan Sanden, yang wilayahnya tidak mencakup gumuk pasir Gunung Wingko, dapat pula menjadi pendukung, misalnya dalam penyediaan penginapan, kuliner dan oleh-oleh bagi pengunjung Pusat Informasi Situs Gunung Wingko, serta atraksi lainnya. Kesiapan Kecamatan Sanden untuk mendukung wisata minat khusus dapat diketahui dari potensi yang ditampilkan tiap tahun dalam Sanden Fair. Saat ini homestay yang sering didatangi tamu manca negara sudah ada di Desa Gadingharjo, misalnya Puri Brata, di Dusun Kalimundu. Desa Gadingharjo juga menjadi sentra jamu yang sering dikunjungi oleh wisatawan. Diharapkan dalam beberapa tahun ke depan adanya minat dan kepedulian masyarakat luas terhadap Situs Gunung Wingko dapat menjadi penggerak kesadaran masyarakat lokal akan pentingnya situs dan upaya pelindungannya. Kelak dengan kesadaran tersebut masyarakat lokal diharapkan dapat mengelola situs secara mandiri dan arif dalam memelihara keberadaan dan kondisi gumuk pasir, agar tetap lestari.

\section{Penutup}

Kepentingan masing-masing stakeholder terhadap keberadaan Situs Gunung Wingko saat ini belum sejalan. Oleh karena itu, sosialisasi rencana dan dampak kegiatan yang berkaitan dengan langkah-langkah penetapan Cagar Budaya, perlu dilakukan. Dialog menjadi salah satu upaya yang penting untuk mengetahui aspirasi para stakeholder. Dampak ekonomi, baik positif maupun negatif, pasca penetapan Gunung Wingko sebagai Cagar Budaya, perlu dijelaskan kepada masyarakat setempat agar konflik kepentingan antarstakeholder dapat dihindari. Pendampingan kepada masyarakat perlu dilakukan terus menerus, baik untuk menggali potensi ekonomi yang menunjang pemanfaan situs maupun untuk menjaga kelestarian situs. Tanpa pendampingan yang memadai, ancaman terhadap kelestarian situs bisa menjadi semakin besar dan Situs Gunung Wingko benar-benar hanya tinggal nama saja.

\section{Referensi}

Alifah. (2012a). Jejak Industri Kerajinan dalam Artefak Gerabah. Mata Jendela Vol. VII, No. 4: 9-14.

(2012b). Pemanfaatan Hasil Penelitian Situs Gunung Wingko. Berkala Arkeologi Vol. 33 No. 1: 66. 
Anggraeni. (2018). Pelibatan Masyarakat dalam Pengelolaan Situs Gunung Wingko, Bantul. Jurnal PkM Bakti Budaya Vol.1, No.2: 153-165

Nitihaminoto, Gunadi. (1974). Laporan Penggalian Prasejarah Gunung Wingko Tahap I dan II. Lembaga Purbakala dan Peninggalan Nasional, Prambanan

(1999). Karakter dan Perkembangan Permukiman Situs Prasejarah Gunungwingko. Berita Penelitian Arkeologi No. 06. Yogyakarta: Balai Penelitian Arkeologi Yogyakarta.

. (2001). Situs Gunung Wingko: Sebuah Rekonstruksi Kehidupan

Masyarakat Akhir Perundagian. Disertasi. Fakultas Pascasarjana Universitas Gadjah Mada, Yogyakarta

Prayudi, Ashwin dan Rusyad Adi Suriyanto. (2019). Studi Patologi dan Kultural pada 19 Gigi Lepas dari Kotak TP GEO IV Gunungwingko. Berkala Arkeologi Vol. 39, No.1: 1-16

Rangkuti, Nurhadi dkk. (2018). Gunungwingko: Situs Penanda Kehidupan Pesisir Selatan Sejak Awal Masehi hingga Abad XVII. Yogyakarta: Dinas Kebudayaan DIY, Pemerintah Daerah DIY.

Sunarto. (1986). Pendekatan Pedogeomorfologi dalam Penelitian Arkeologi di Gunung Lanang dan Gunung Wingko (Bantul). Berkala Arkeologi VII (1): 27-38. 